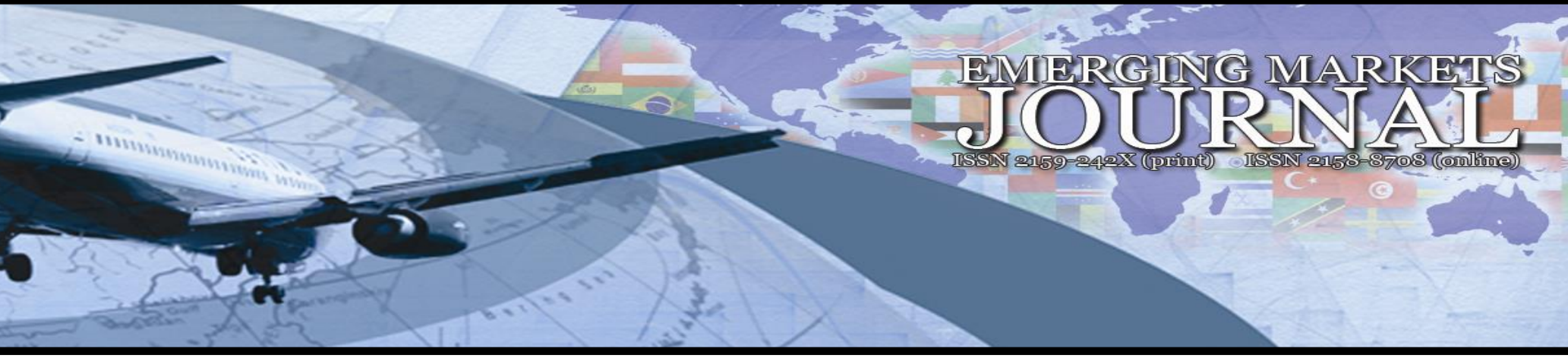

\title{
Examination of Consumption Expenditure Distribution among NUTS-2 Regions in 2007-2018 with GINI Coefficient
}

\section{Latif Öztürk}

Kırıkkale University, Turkey | e-mail: latifozturk6@yahoo.com

\section{Nimet Varlık}

Kırıkkale University, Turkey | e-mail: nvarlik@kku.edu.tr

Volume 11 No 1 (2021) ｜ ISSN 2158-8708 (online) ｜ DOI 10.5195/emaj.2021.223 | http://emaj.pitt.edu

\begin{abstract}
In this study, the distribution of 12 main expenditure categories included in the consumer price index (CPI) among NUTS-2 (Nomenclature of Territorial Units for Statistics-2) regions is examined. The study covers the years 2007-2018. In the study, interregional consumption expenditure rates are identified with the Gini coefficient, which is a measure of inequality and the obtained consumption expenditure rates through the years are interpreted. The coefficients calculated for each expenditure category are important in terms of revealing the course of consumption behavior of households in Turkey over the years and reflecting the best and worst distribution at the NUTS-2 level. Findings regarding the expenditure categories show that the consumption behavior in Turkey in the relevant period is far from equal at the regional level. According to the findings, the expenditure category with the highest inequality at the NUTS-2 level is the food and non-alcoholic beverages category with an average Gini coefficient of 0.3031 . The expenditure category with the highest equal distribution, on the other hand, is the education category with a Gini coefficient of 0.2307 according to the findings.
\end{abstract}

Keywords: NUTS-2, Consumer Consumptions, Consumer Price Index, Lorenz Curve, Gini Coefficient

\section{$(\mathrm{Cc}) \mathrm{EY}$}

New articles in this journal are licensed under a Creative Commons Attribution 3.0 United States License.

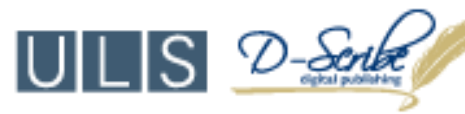

This journal is published by the University Library System of the University of Pittsburgh as part of its D-Scribe Digital Publishing Program, and is cosponsored by the University of Pittsburgh Press. 


\section{Examination of Consumption Expenditure Distribution among NUTS-2 Regions in 2007-2018 with GINI Coefficient}

\section{Latif Öztürk Nimet Varlık}

\section{Introduction}

Economic policies aim to increase the welfare level of all individuals and social groups in an economy. At this point, the distribution of the total income in an economy in a certain period among individuals, households, social groups, regions, or elements of production defines income distribution by definition. Income distribution, which is one of the important indicators of the economy, is a factor that directs the consumption behavior of consumers to a great extent. Consumption behavior is an important indicator of household welfare. Consumption expenditures are also frequently used in income distribution calculations in the economics literature.

Numerical analysis of household consumer behavior at different income levels began to gain momentum in the late 1700s. In the 1790s, two researchers, David Davies and Frederick Eden analyzed the expenditure distribution of particularly poor families in England among food, fuel, rent, clothing, health, and other expenditure categories. Then, among the researchers who developed statistical techniques related to social data in the 1850s, Adolphe Quételet was the pioneer of studies examining individual behaviors through aggregated data. Inspired by previous researchers and Quételet, German statistician Ernst Engel analyzed the relationship between the income level of socio-economic classes living in Belgium and the expenditure categories in 1857. As a result of his research with 153 families, Engel came up with a consumption law. According to this, the poorer a family is, the higher the share it will allocate for food in its total expenditures. This was Engel's first general finding from the data regarding the budget of families. In 1895, Engel examined the expenditure categories according to income levels. The findings of this study revealed that as the income increases, the share consumers allocate for clothing in total expenditures increases, as well as the share they allocate for housing and fuel decreases (Stigler, 1954). These findings have been incorporated into economic theory as the Engel curve or the Engel's law.

Consumer spending from their budget for various expenditure categories varies in different income levels. In addition, the spending behaviors of households living in different geographical regions and having different demographic characteristics also vary. ${ }^{1}$ At this point, the interaction between theoretical thought and empirical studies and rapid advances in data acquisition provided an attractive opportunity to investigate household spending behaviors (Blundell, 1988). Many studies in economics literature examine the consumption expenditures of consumers, that is, the shares they allocate for different expenditure categories from their budgets. Houthakker's 1952 study, which is one of the studies that use the traditional approach to calculate expenditure elasticity values ${ }^{2}$, examines household expenditures on food, rent, clothing, and other expenditure categories in 30 countries and the relationship between these expenditures and family size. The findings show that expenditure elasticity values of households are similar but not the same. Giles and Hampton (1985) examined the expenditures of households in seven different expenditure categories in New Zealand and found that their expenditure elasticity was quite low. The authors compared their findings with the results they obtained from their studies for Australia, England, and the United States of America. The estimations made by Chung, Lee, and Brown (2002) using the expenditure data of Taiwanese households for the period 1996-1998 regarding ten commodity categories coincide with the findings of Giles and Hampton (1985). McDowell et al. (1997) examined household consumption expenditures from the aspect of income levels and found that especially food consumption expenditures vary to a great extent among different income levels. Djibuti et al. (2007), in their study for independent states including Russia, reveals the relationship between household expenditures and demographic and socio-economic factors. According to this study, tobacco expenditures of highly rich families are significantly higher than those of poor families.

In studies using the Lorenz curve, expenditure elasticity values of all expenditure categories are calculated by using the estimation parameters obtained from the Lorenz curve (Chung, Lee, \& Brown; 2002). The Lorenz curve was created in 1905 and it is a graphical representation of the wealth density among a group of households and is a measure of income inequality. Although the estimations made with the Gini coefficient provide accurate and precise data on income distribution, it is argued that the obtained estimations

${ }^{1}$ This difference in consumption expenditure is explained by income elasticity in microeconomic theory. Goods with positive income elasticity (normal goods) are goods for which demand increases as the income of the consumer increases, while goods with negative income elasticity (inferior goods) are those for which demand decreases as the income of the consumer increases. Therefore, the factor that determines the direction of demand here is the quality of the good. This is what Engel's analysis of commodity groups indicates.

${ }^{2}$ Studies using the traditional approach to estimate the elasticity of expenditure generate an appropriate functional form for each category of goods and thus obtain an elasticity value at any level of total expenditure (Chung, Lee, \& Brown, 2002). This approach is based on the evaluation of the elasticity coefficients estimated from the Engel curves. 
should be based on the tables obtained from the Lorenz curve (Fellman, 2012). The Lorenz curve is widely used to represent and analyze household consumption expenditures and income or wealth distribution (Akbay, 2005; Bhattacharya, 2007; Kakwani and Podder, 2008; Filiztekin and Çelik, 2010; Kabaş, 2010; Dutta and Panda, 2014; Lyon and Gastwirth, 2016; Zhang et al., 2019).

In 1987, the Household Income and Consumption Expenditures Survey was applied for the first time in Turkey to cover the whole country. This survey includes information showing that income and consumption expenditures vary in different regions, population strata, and rural and urban areas. The 1994 Household Income and Consumption Expenditure Survey was prepared separately to identify consumption expenditures and income distribution with a different method. With this survey, indicators related to consumption expenditures and income distribution in urban and rural areas throughout Turkey were obtained. However, in 2003, during the process of adaptation to the European Union (EU) and in order to form a basis for the harmonized index of consumer prices that has been implemented in 2003, it started to be applied with a new name, "Household Budget Survey" (TÜİK, 2018). In Turkey, Akbay and Bilgiç (2011) estimated the general consumption and food expenditures of households and the income elasticity of food subcategories. Their findings show that housing and rent expenditures have the highest percentage in total consumption expenditures with $29.1 \%$ and food consumption expenditures take second place with $22.6 \%$ in Turkey. Çağlayan and Astar (2012) estimated the determinants of household consumption expenditures separately in Turkey, using the 2009 Household Budget Survey data from the Turkish Statistical Institute (TURKSTAT). The findings indicate that consumption expenditures in rural and urban areas differ depending on various factors (such as age, gender, household size). The study in which Şengül and Sigeze (2013) examined the expenditure categories for Turkey between 2005 and 2009 shows that the expenditure elasticity values of food and non-alcoholic beverages, clothing and shoes, housing, water, electricity, fuel, furniture and household appliances, communication, alcoholic beverages, cigarettes, and tobacco are low. Expenditures for health, transportation, education, cultural activities and entertainment, restaurant, hotel, and pastry categories vary to a great extent depending on income level. Yereli and Şahin (2014), based on the Household Budget Survey data from the years 20022009 , examined the budget shares of households for 12 different expenditure categories in Turkey. Housing and rental expenditures took the highest share according to expenditure ratios, while communication expenditures took the lowest. Y1lmaz's (2014) study reveals the effect of inequality in income distribution on the distribution of consumption expenditures. For this purpose, Lorenz curves were created for total income and 13 expenditure categories from TURKSTAT 2008 household consumption expenditure data, and Gini coefficients for these Lorenz curves were calculated. According to the Gini coefficients, there are relatively unequal spending behaviors in Turkey.
In this study, consumer price index (CPI) main expenditure categories are discussed in terms of total expenditure rates at the NUTS-2 level (Nomenclature of Territorial Units for Statistics-2), unlike other studies in the economics literature that discuss them in terms of income levels. In the study covering the 2007-2018 period, the distribution of each of the 12 main expenditure categories to the total consumption expenditures among the regions is identified using the Gini coefficient, which is an indicator of inequality, and the consumption expenditure rates over the years are interpreted. The empirical findings show that the expenditure category with the highest inequality at the NUTS-2 level in the specified period is the food and nonalcoholic beverages category, and the expenditure category with the highest equal distribution is the education category.

The study consists of four sections. After the introduction section, in which the theoretical and empirical literature is explained, the data are introduced and the method of the study is explained in the second section. In the third section, the findings of the analyses are given. The fourth section consists of the results and conclusion.

\section{Data and Methodology}

In the study, the data used to measure the inequality of distribution of expenditure rates based on population are:

i) Consumption expenditure rates based on NUTS-2 for 12 consumption expenditure categories from TURKSTAT for the period 2003-2018, "Distribution of expenditure categories based on Nomenclature of Territorial Units for Statistics-2"3,

ii) Population data obtained from the population statistics from ADNKS (Address Based Population Registration) system of TURKSTAT. ${ }^{4}$

The Gini coefficient has been used to measure the inequalities of the distribution of expenditure rates based on population, and the Lorenz curve has been used for its graphical representation. The Gini coefficient was first used in 1912 by the Italian scientist Corrado Gini to identify the inequalities in income distribution. Today, this coefficient is also used in different fields in which inequality in distributions needs to be measured.

Besides various calculation methods, the Gini coefficient was defined by Brown in 1994 as follows (Brown, 1994; Öztürk and Aktar, 2009):

$G=1-\sum_{k=1}^{n-1}\left(Y_{k+1}+Y_{k}\right)\left(X_{k+1}-\right.$

$\left.Y_{k}\right)$

$$
\begin{aligned}
& Y_{k}=\text { Expenditure category rates by region } \\
& X_{k}=\text { Population density of the regions by years } \\
& k=1, \ldots, n
\end{aligned}
$$

${ }^{3}$ https://tuikweb.tuik.gov.tr/PreTablo.do?alt_id=1012
${ }^{4}$ https://tuikweb.tuik.gov.tr/PreTablo.do?alt_id=1059 
The Gini coefficient takes a value between 0 and 1 . A value of zero indicates absolute equality and a value of one indicates absolute inequality. Accordingly, a Gini coefficient approaching zero indicates that inequality decreases, while a value close to one indicates that inequality increases.

The representation of the Lorenz curve and the Gini coefficient is as follows:

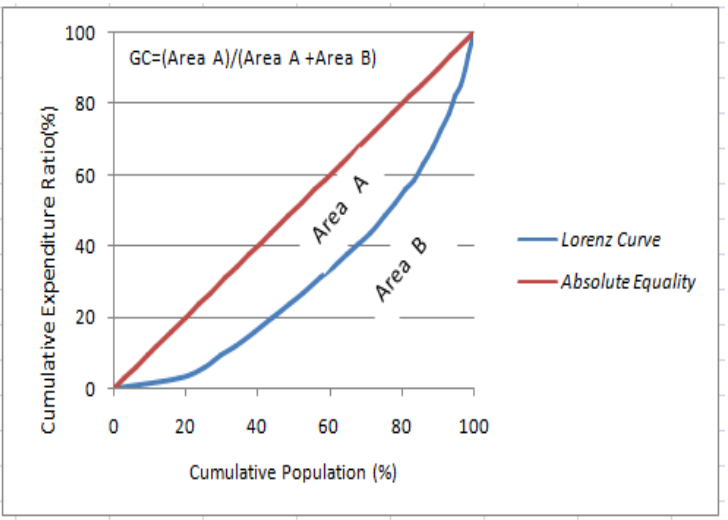

Figure 1. Lorenz Curve and Gini Coefficient

Source: Composed by authors

In this study, as shown in Figure 1, the cumulative population on the horizontal axis in the representations on the Lorenz curve, and the cumulative percentages of the spending rates within the general expenditure categories of various spending groups on the vertical axis are shown. The study also analyzes the relationships among these calculated coefficients and the income distribution coefficients calculated by TURKSTAT.

\section{Analysis and Findings}

In the study, it is examined whether the ratio of 12 $\mathrm{CPI}$ main expenditure categories to general expenditure is evenly distributed among the regions between 2007 2018 in Turkey. For this purpose, Gini coefficients have been calculated for 12 expenditure categories in the study. The coefficients calculated separately for each year and each expenditure category are important in terms of revealing the course of household consumption behaviors over the years and reflecting the best and worst distribution for each year.

The Gini coefficients calculated for 12 expenditure categories and the course of these coefficients over the years (2007-2018) are presented below through tables and figures. In the study, 12 expenditure categories are presented with tables and figures in groups of 3.

The course of the Gini coefficients of a-) Food and Non-Alcoholic Beverages, b-) Alcoholic Beverages, Cigarettes and Tobacco, c-) Clothing and Footwear expenditure categories over the years are indicated in Table 1 and Figure 2.
Table 1: Gini Coefficients of Expenditure Categories for Food and Non-Alcoholic Beverages, Alcoholic Beverages, Cigarettes and Tobacco and Clothing and Footwear by Years

\begin{tabular}{lccc}
\hline Year & $\begin{array}{c}\text { Food and Non-Alcoholic } \\
\text { Beverages }\end{array}$ & $\begin{array}{c}\text { Alcoholic Beverages } \\
\text { Cigarettes and Tobacco }\end{array}$ & Clothing and Footwear \\
\hline 2007 & 0,3037 & 0,2735 & 0,2919 \\
\hline 2008 & 0,3025 & 0,2797 & 0,2842 \\
\hline 2009 & 0,2961 & 0,289 & 0,291 \\
\hline 2010 & 0,3025 & 0,2867 & 0,2923 \\
\hline 2011 & 0,3005 & 0,2928 & 0,286 \\
\hline 2012 & 0,3013 & 0,2911 & 0,279 \\
\hline 2013 & 0,3051 & 0,3037 & 0,2746 \\
\hline 2014 & 0,3037 & 0,3017 & 0,277 \\
\hline 2015 & 0,3109 & 0,3093 & 0,275 \\
\hline 2016 & 0,3083 & 0,3102 & 0,2814 \\
\hline 2017 & 0,3072 & 0,3136 & 0,2828 \\
\hline 2018 & 0,3007 & 0,3142 & 0,2822 \\
\hline
\end{tabular}

Source: Composed by authors

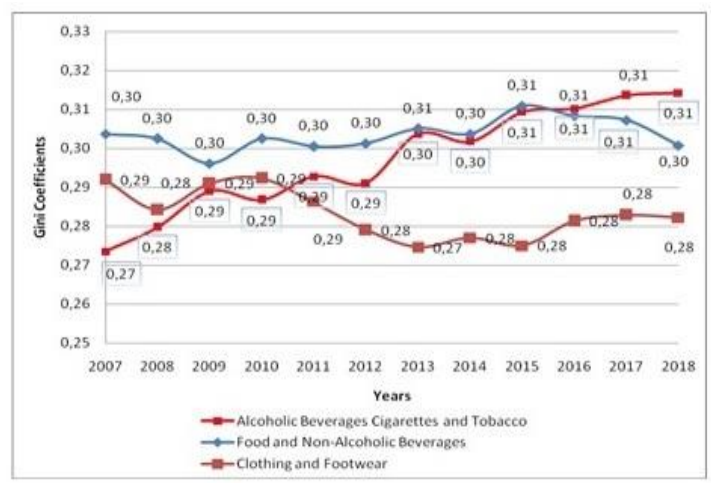

Figure 2. The Course of the Gini Coefficients of the Inequalities of Expenditure Rates at the NUTS-2 Regional Level between 2007 and 2018

Source: Composed by authors

Table 1 and Figure 2 show the Gini coefficients of the three main expenditure categories and the course of these coefficients over the years. These expenditure groups are (a) food and non-alcoholic beverages, (b) alcoholic beverages, cigarettes, and tobacco, and (c) clothing and footwear. In the food and non-alcoholic beverages category, the lowest Gini coefficient $(0.29$, the best distribution) was in 2009, and the highest Gini coefficient $(0.31$, the worst distribution) was in 2015 . In the remaining years, expenditures on food and nonalcoholic beverages were almost equally distributed among regions. It is noteworthy that the Gini coefficient of the alcoholic beverages, cigarettes, and tobacco category has increased continuously from 2007 to 2018, in other words, there has been a trend towards inequality between regions in this expenditure category over the years. Accordingly, in the alcoholic beverages, cigarettes, and tobacco category, the lowest Gini coefficient was observed in 2007 (0.2775), and the highest Gini coefficient was observed in 2018 (0.3142). It is seen that the Gini coefficients of the clothing and footwear category are lower than the other two main expenditure categories over the years. This finding shows that the 
expenditures of the clothing and footwear category are relatively more evenly distributed compared to the other two main expenditure categories. In this expenditure category, the highest Gini coefficient $(0.2923$, the worst distribution) was in 2010, and the lowest Gini coefficient (0.2746, the best distribution) was in 2013. According to the findings, among the three main expenditure categories shown in Figure 1, the expenditure category with the worst distribution at the regional level by years (the highest average Gini coefficient) is alcoholic beverages, cigarettes, and tobacco.

Among other expenditure categories, the course of Gini coefficients of d-) Housing and rental, e-) Furniture and household appliances, f-) health expenditure categories by years can be seen in Table 2 and Figure 3 .

Table 2: Gini Coefficients of Housing and Rental, Furniture and Home Appliances, and Health Expenditure Categories by Years

\begin{tabular}{cccc}
\hline Year & $\begin{array}{c}\text { Housing } \\
\text { and } \\
\text { Rental }\end{array}$ & $\begin{array}{c}\text { Furniture } \\
\text { and Home } \\
\text { Appliances }\end{array}$ & Health \\
\hline 2007 & 0,2382 & 0,2879 & 0,2600 \\
\hline 2008 & 0,2329 & 0,2967 & 0,2665 \\
\hline 2009 & 0,2278 & 0,2770 & 0,2728 \\
\hline 2010 & 0,2238 & 0,2797 & 0,2731 \\
\hline 2011 & 0,2271 & 0,2740 & 0,2771 \\
\hline 2012 & 0,2352 & 0,2700 & 0,2779 \\
\hline 2013 & 0,2438 & 0,2608 & 0,2679 \\
\hline 2014 & 0,2499 & 0,2578 & 0,2557 \\
\hline 2015 & 0,2519 & 0,2701 & 0,2385 \\
\hline 2016 & 0,2554 & 0,2742 & 0,2469 \\
\hline 2017 & 0,2507 & 0,2755 & 0,2627 \\
\hline 2018 & 0,2422 & 0,2749 & 0,2765 \\
\hline
\end{tabular}

Source: Composed by authors

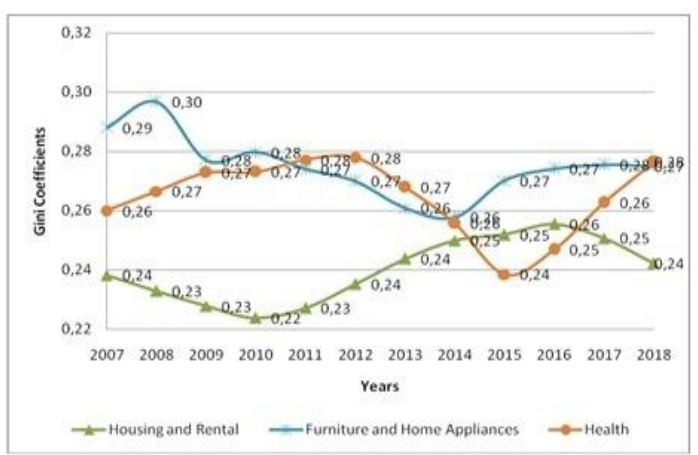

Figure 3. The Course of Gini Coefficients of Inequalities of Expenditure Rates at NUTS-2 Level Regions between 2007-2018
Table 2 and Figure 3 show the Gini coefficients of (d) housing and rent, (e) furniture and household appliances, and (f) health expenditure categories and the course of these coefficients over the years. In the housing and rent expenditure category, the year with the lowest inequality between regions is 2010 , and the year with the highest is 2016. In addition, the findings show that the inequality in the interregional consumption expenditure rates of this group between 2012 and 2016 was higher than in other years and that inequality started to decrease after 2016. In the furniture and household appliances category, the lowest Gini coefficient was 0.258 in 2014 and the highest Gini coefficient was 0.297 in 2009. When the Gini coefficients of health expenditures are examined, it is seen that the best distribution occurred in 2015 (0.239). The inequality among regions, which has increased continuously after 2015 , went up to 0.278 in 2018. Among the three main expenditure categories shown in Figure 3, the best distribution by years was in the housing and rent category, and the worst distribution was in the furniture and household appliances category.

Table 3: Gini Coefficients of Transportation, Communication, Cultural Activities and Entertainment Expenditure Categories by Years

\begin{tabular}{cccc}
\hline Year & Transportation & Communication & $\begin{array}{c}\text { Cultural } \\
\text { Activities } \\
\text { and } \\
\text { Entertain } \\
\text { ment }\end{array}$ \\
\hline 2007 & 0,2544 & 0,2574 & 0,2561 \\
\hline 2008 & 0,2585 & 0,2515 & 0,2732 \\
\hline 2009 & 0,2657 & 0,2547 & 0,246 \\
\hline 2010 & 0,2658 & 0,2515 & 0,2301 \\
\hline 2011 & 0,2627 & 0,2581 & 0,2285 \\
\hline 2012 & 0,2646 & 0,262 & 0,2487 \\
\hline 2013 & 0,2613 & 0,2634 & 0,2555 \\
\hline 2014 & 0,2617 & 0,2638 & 0,2641 \\
\hline 2015 & 0,2618 & 0,2643 & 0,257 \\
\hline 2016 & 0,2635 & 0,2627 & 0,2588 \\
\hline 2017 & 0,2724 & 0,2642 & 0,2528 \\
\hline 2018 & 0,2772 & 0,2591 & 0,2435 \\
\hline
\end{tabular}

Source: Composed by authors

Source: Composed by authors

Examination of Consumption Expenditure Distribution among NUTS-2 Regions in 2007-2018 with GINI Coefficient 


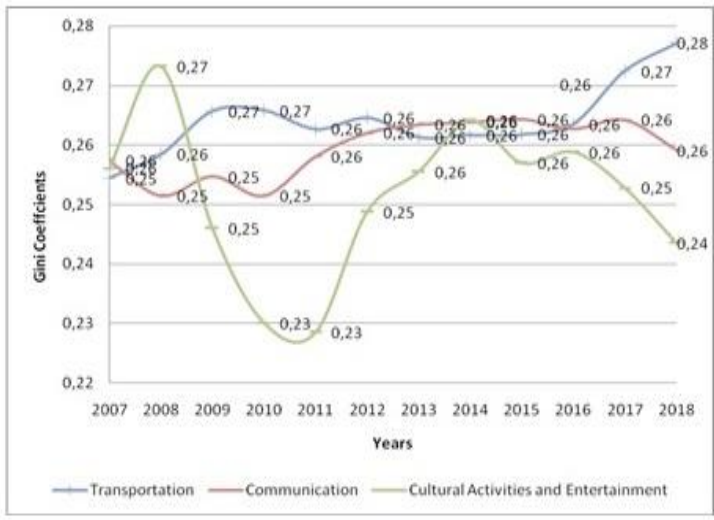

Figure 4. The Course of Gini Coefficients of Inequalities of Expenditure Rates at NUTS-2 Level Regions between 2007-2018

Source: Composed by authors

In Table 3 and Figure 4, (g) Transportation, (h) communication, and (i) cultural activities and entertainment expenditure categories are shown. According to this, the lowest Gini coefficient in the transportation category was 0.2544 in 2007 , and the highest Gini coefficient was 0.2778 in 2018 . When we look at the general course, it is seen that the expenditure rates at the level of the regions in the transportation category have a similar distribution, but there is a trend towards inequality in 2017 and 2018. In the communication expenditure category, the best distribution was in 2008 and 2010, and the worst distribution was in 2015. In the cultural activities and entertainment expenditure category, it is seen that the inequality among the regions is high over the years. According to the findings of this category, the lowest Gini coefficient (best distribution) was 0.2285 in 2011, and the highest Gini coefficient (worst distribution) was 0.2732 in 2008 . The findings show that among the three expenditure categories in Figure 3, the best distribution by years is in the cultural activities and entertainment category. It has been observed that the average Gini coefficients in the transportation and communication categories are quite close to each other over the years. This finding shows that the distribution at the regional level is almost equal in these two main expenditure categories.
Table 4: Gini Coefficients of Education, Restaurants, and Hotels, and Other Goods and Services Expenditure Categories by Years

\begin{tabular}{cccc}
\hline Year & Education & $\begin{array}{c}\text { Restaurants } \\
\text { and Hotels }\end{array}$ & $\begin{array}{c}\text { Other Goods and } \\
\text { Services }\end{array}$ \\
\hline 2007 & 0,261 & 0,247 & 0,270 \\
\hline 2008 & 0,254 & 0,246 & 0,273 \\
\hline 2009 & 0,256 & 0,255 & 0,279 \\
\hline 2010 & 0,237 & 0,250 & 0,279 \\
\hline 2011 & 0,246 & 0,250 & 0,284 \\
\hline 2012 & 0,208 & 0,245 & 0,280 \\
\hline 2013 & 0,208 & 0,247 & 0,278 \\
\hline 2014 & 0,218 & 0,237 & 0,277 \\
\hline 2015 & 0,230 & 0,232 & 0,261 \\
\hline 2016 & 0,231 & 0,238 & 0,259 \\
\hline 2017 & 0,230 & 0,249 & 0,258 \\
\hline 2018 & 0,216 & 0,256 & 0,251 \\
\hline
\end{tabular}

Source: Composed by authors

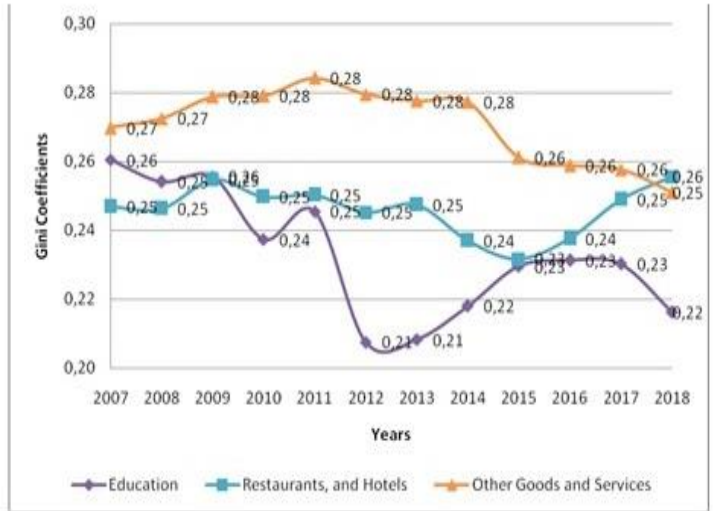

Figure 5. The Course of Gini Coefficients of Inequalities of Expenditure Rates at NUTS-2 Level Regions between 2007-2018

Source: Composed by authors

Figure 5 and Table 4 show (j) education, (k) restaurants and hotels, (m) other goods and services expenditure categories. In the education category, the inequality at the regional level by years was the lowest in 2018 (0.2163). The worst distribution occurred with 0.2605 in 2007. In the restaurants and hotels expenditure category, the best year was 2015 and the worst year was 2018. In other goods and services, 2015 has the best distribution, while 2010 has the worst distribution. Among the three expenditure categories in the graph, the best distribution among regions by years is seen in the education expenditure category. Other goods and services category has the worst distribution. 


\section{Conclusion}

In the study, the ratio of the 12 main expenditure categories under the CPI to the total consumption expenditures was identified with the Gini coefficient among the regions at the NUTS-2 level. In the study covering the years 2007-2018, the Gini coefficient calculated for each main expenditure category based on years shows the good and bad distribution characteristics of consumption behaviors by to the expenditure categories. According to this, a Gini coefficient approaching zero indicates that inequality decreases, while a value close to one indicates that inequality increases.

According to the empirical findings, the highest average Gini coefficient of 0.3031 among the 12 main expenditure categories over the years was in the food and non-alcoholic beverages category. This finding shows that the expenditure category with the highest inequality among regions is food and non-alcoholic beverages. Considering that food expenditures are the most important expenditure category closely related to household incomes and its share in total expenditure is considered, it is significant that the inequality between regions is high in this expenditure category. The worst distribution in this category occurred in 2015. Another expenditure category with high inequality is alcoholic beverages, cigarettes, and tobacco. According to the findings, the level of inequality in this category has continuously increased after 2013. In the clothing and footwear category, it is seen that the inequality among regions is high with an average of 0.2825 . The following expenditure categories are furniture and household appliances, health, transportation, and communication categories (average Gini coefficients 0.2745; 0.2672; $0.2631 ; 0.2605$, respectively, over the years).

The expenditure category with the highest equal distribution among the regions over the years is the education category with an average Gini coefficient of 0.2307. Considering that the share of education expenditures in total expenditures is quite low, it is an expected finding that the distribution in the education category at the level of regions is relatively high. In this category, the best distribution was in 2012 and the worst distribution was in 2007. Another expenditure category where inequality is relatively low compared to other expenditure categories is housing and rent. According to the findings, the best distribution of housing and rental expenditures between regions is the period between 2007-2011. In this category, it is noteworthy that inequality has gradually increased from 2012 to 2018 . The other expenditure category that follows the education category towards equal distribution is restaurants and hotels. While the best distribution was in the restaurant and hotels category in 2015, the worst distribution was seen in 2018 .

\section{References}

Akbay, C. (2005). Kahramanmaraş'ta hanehalklarının gida tüketim talebi ekonometrik analizi. KSÜ Fen ve Mühendislik Dergisi, 8(1), 114-121.
Akbay, C., and Bilgiç, A. (2011). Türkiye'de 2003-2008 Dönemlerinde Tüketim Harcamaları ile Gıda Harcamalarında Meydana Gelen Değişimler. Turkish Journal of Agricultural Economics, 17.

Bhattacharya, D. (2007). Inference on inequality from household survey data. Journal of Econometrics, 137(2), 674-707.

Blundell, R. (1988). Consumer behaviour: theory and empirical evidence - a survey. The economic journal, 98(389), 16-65.

Brown, M. C. (1994). Using Gini-style indices to evaluate the spatial patterns of health practitioners: theoretical considerations and an application based on Alberta data. Social science \& medicine, 38(9), 1243-1256.

Chung, R. H., Lee, J. Y. and Brown, M. G. (2002). An Engel Curve Analysis of Household Expenditure in Taiwan: 1996-98 (No. 8232016-54542).

Çağlayan, E. and Astar, M. (2012). A Microeconometric Analysis of Household Consumption Expenditure Deternşnants for Both Rural and Urban Areas in Turkey. American International Journal Of Contemporary Research, 2(2): 2734.

Djibuti, M., Gotsadze, G., Mataradze, G., and Zoidze, A. (2007). Influence of household demographic and socio-economic factors on household expenditure on tobacco in six New Independent States. BMC Public Health, 7(1), 1-6.

Dutta, B., and Panda, M. (2014). Social Welfare and Household Consumption Expenditure in India2004-05 to 2011-12. Economic and Political Weekly, 113-121.

Fellman, J. (2012). Estimation of Gini coefficients using Lorenz curves. Journal of Statistical and Econometric Methods, 1(2), 31-38.

Filiztekin, A., and Çelik, M. A. (2010). Türkiye'de bölgesel gelir eşitsizliği (Regional income inequality in Turkey). Megaron, 5(3), 116-127.

Houthakker, H.S., (1957). "An International Comparison of Household Expenditure Patterns, Commemorating the Centenary of Engel's Law", Econometrica, 25(4) (Oct.). 532-551.

Giles, D. E. A., and Hampton, P., (1985). “An Engel Curve Analysis of Household Expenditure in New Zealand", The Economic Record, March, 450-462.

Kabaş, T. (2010). Türkiye'de En Yoksul \% 20'nin Yoksulluk Profili, Gelir Dağılımı ve Tüketim Harcamas1, Journal of the Cukurova University Institute of Social Sciences, 19(2). 
Kakwani, N. C., and Podder, N. (2008). Efficient estimation of the Lorenz curve and associated inequality measures from grouped observations. In Modeling Income Distributions and Lorenz Curves (pp. 57-70). Springer, New York, NY.

Lyon, M., Cheung, L. C., and Gastwirth, J. L. (2016). The advantages of using group means in estimating the Lorenz curve and Gini index from grouped data. The american statistician, 70(1), 25-32.

McDowell, D. R., Allen-Smith, J. E., and McLeanMeyinsse, P. E. (1997). Food expenditures and socioeconomic characteristics: Focus on income class. American Journal of Agricultural Economics, 79(5), 1444-1451.

Öztürk, L., Aktar İ. (2009). Karadeniz Bölgesi İllerinde Kamu Tarım Yatırımları Dağılımının Gini Katsayısı İle Ölçülmesi, Karadeniz Araştırmaları, Cilt: 6, Sayı: 21, s.113-122.

Stigler, G. J. (1954). The early history of empirical studies of consumer behavior. Journal of Political Economy, 62(2), 95-113.

Şengül, S. and Çiler S. (2013). Türkiye'de Hanehalk1 Tüketim Harcamaları: Psudo Panel Veri İle Talep Sisteminin Tahmini, International Conference On Eurasian Economies, 17-18 Temmuz 2013, St. Petersburg, Rusya S. 279288.

Türkiye İstatistik Kurumu, TÜİK. (2018). Hanehalk1 Bütçe İstatistikleri Mikro Veri Seti, Yayın no: 4557.

https://www.tuik.gov.tr/media/microdata/pdf/h anehalki-butce.pdf, Erişim tarihi 25.02.2021.

Yereli, A. B., and Şahin, I. F. O. (2014). Türkiye'deki Hanehalklarının Haberleşme Talebinin Ampirik Analizi. Sosyoekonomi, 21(21).

Yılmaz, H. İ. (2014). Türkiye'de Gelir Dağılımının Kentsel ve Kırsal Alanda Tüketim Harcamalarına Etkisi: Ekonometrik Bir İnceleme, Yayınlanmamış Yüksek Lisans Tezi, Kahramanmaraş Sütçü İmam Üniversitesi, Sosyal Bilimler Enstitüsü.

Zhang, Q., Bilsborrow, R. E., Song, C., Tao, S., and Huang, Q. (2019). Rural household income distribution and inequality in China: Effects of payments for ecosystem services policies and other factors. Ecological Economics, 160, 114127.

\section{APPENDIX}

Appendix 1: Representation of the Lowest and Highest Gini Coefficients (GK) calculated over the Years on the Basis of Expenditure Categories with the Lorenz Curve
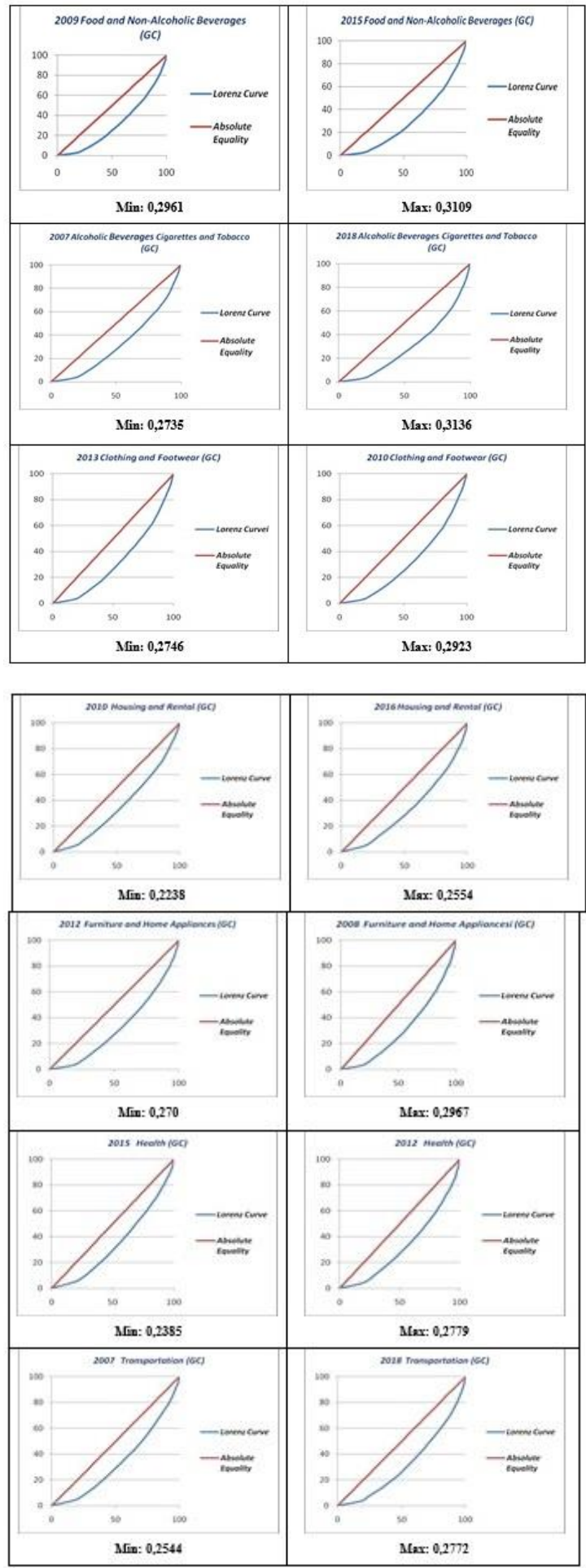

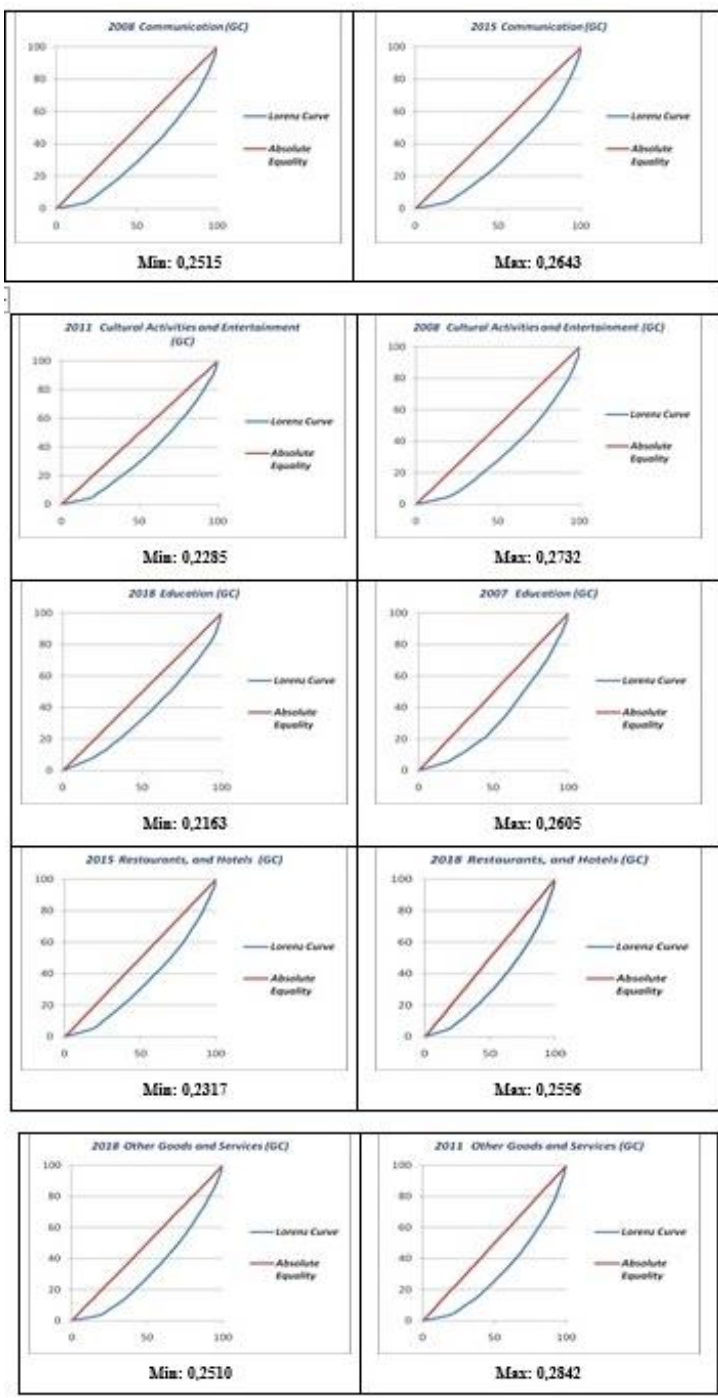

Examination of Consumption Expenditure Distribution among NUTS-2 Regions in 2007-2018 with GINI Coefficient 